\title{
İslam Karşıtı Söylemi Bilimsellik Kisvesine Büründürmek: Hans G. Kippenberg Örneği
}

Araștırma makalesi / Research article

Ramazan ADIBELLí⿱艹

Disguising Anti-Islamic Discourse in Science Package: The Case of Hans G. Kippenberg

Citation/@: Adibelli, Ramazan, (2020). Disguising Anti-Islamic Discourse in Science Package: The Case of Hans G. Kippenberg, Milel ve Nihal, 17 (2), 281-297.

Abstract: One of the most important effects of the events of September 11, 2001 was the formation of an extremely negative image in the Western world, which has been prejudiced against Islam for centuries. Islam was according to some a "religion of sword". These events were presented by those people as an incontestable proof that Islam is a "religion of violence". Although not included in the report of the commission, which examined the September 11 attacks to the finest detail, handwritten five-page Arabic letters from the attackers' luggage were put on the market. German historian of religions Hans G. Kippenberg, based on the assumption that these documents are authentic, compared the deeds of the attackers with the campaigns carried out in the time of the Prophet. In this article, by deconstructing Kippenberg's fiction one tried to put forth how it is incompatible with a scientific approach. As a result, it appears that Kippenberg has wanted to gain credibility by putting an ideological and reductionist discourse on a scientific disguise. The Kippenberg example reminds people who serve the discipline such as the History of Religions, which ultimately adopt scientific honesty as a motto, that there should be no myths in a place where historical realities are manifest.

Keywords: History of Religions, Hans G. Kippenberg, Islamophobia, Reductionism, September 11, 2001.

* Prof. Dr, Erciyes Üniversitesi, İlahiyat Fakültesi, Dinler Tarihi Anabilim Dalı [adibelli@erciyes.edu.tr] ORCID: 0000-0002-7398-0017. 
Atıf/C: Adıbelli, Ramazan, (2020). İslam Karşıtı Söylemi Bilimsellik Kisvesine Büründürmek: Hans G. Kippenberg Örneği, Milel ve Nihal, 17 (2), 281297.

Öz: 11 Eylül 2001 olayların en önemli etkilerinden biri İslam’a karşı yüzyıllar boyunca önyargıyla bakan Batı dünyasında son derece olumsuz bir imajın oluşması olmuştur. Bu olaylar bazılarına göre bir "kılıç dini" olan İslam'ın bir "şiddet dini" olduğunu tescillemiş oluyordu. 11 Eylül saldırılarını en ince ayrıntısına kadar inceleyen komisyonun raporunda yer almasa da saldırganların valizlerinden elle yazılmış beş sayfalık Arapça mektuplar piyasa sunulmuştur. Alman dinler tarihçisi Hans G. Kippenberg, bu dokümanların otantik olduğu varsayımından hareketle saldırganların bu eylemlerinin $\mathrm{Hz}$. Peygamber zamanında gerçekleştirilen gazvelere benzediğini savunmaktadır. Bu makalede Kippenberg'in kurgusunun yapı bozumu yapılarak bilimsel bir yaklaşımla bağdaşmadığı ortaya konulmaya çalışılmaktadır. Sonuç olarak Kippenberg'in ideolojik ve indirgemeci bir söylemi bilimsellik kisvesine büründürerek güvenirlik kazandırmak istediği ortaya çıkmaktadır. Kippenberg örneği en nihayetinde bilimselliği şiar edinen Dinler Tarihi gibi disipline hizmet eden insanlara tarihsel gerçekliklerin tebarüz ettiği bir yerde mitlere mahal kalmaması gerektiğini hatırlatmaktadır.

Anahtar Kelimeler: Dinler Tarih, Hans G. Kippenberg, İslamofobi, İndirgemecilik, 11 Eylül 2001.

\section{Giriş}

İslam karşıtı söylem, Hıristiyanların Müslümanlarla karşılaştıkları ilk dönemlerden itibaren ortaya çıkmaya başlamıştır. VIII. yüzyılda İslam karşıtı ilk polemikleri kaleme alan Yuhanna ed-Dımaşki ya da Latince şekliyle Johannes Damascenus'tur (ö. 749). Şam’da Emevi sultanının sarayında görevli olarak çalışan Dımaşki, Orta çağ boyunca hâkim olacak teolojik İslam algısının ilk önemli temsilcisidir. Dımaşki'nin Hz. Muhammed'in "sahte" bir peygamber, tebliğ ettiği dinin yeni bir vahiy değil, Hıristiyanlığın içinden çıkmış "sapkın bir mezhep" olduğu yönündeki eleştirilerine Orta çağ boyunca başkaları da eklenmiştir. Dımaşki'nin sözde "sahte peygamber" şeklinde betimlediği Peygamber imajı, Avrupalılar tarafından yüzyıllar boyunca kendi eserlerinde olduğu gibi kullanılmıştır. Bu kitapların sunduğu Muhammed imajı, Orta çağlardan günümüze kadar Avrupa'nın İslam Peygamberi algısını belirlemiştir. Bu literatürde Hz. Peygamber, insanları büyü yoluyla kandıran, kendisi de psikolojik olarak hasta, şehvet düşkünü olduğu için çok eşli olan ve müntesip- 
İslam Karşıtı Söylemi Bilimsellik Kisvesine Büründürmek: Hans G. Kippenberg Örneği lerini de buna teşvik eden, düşmanlarına karşı merhametsiz, Hıristiyanlığı ortadan kaldırmak isteyen bir sahte peygamber ve nihayet "deccal" (anti-Christ) olarak sunulur.

İslam'nn bir şiddet dini olduğu ya da diğer bir ifadeyle şiddet kaynağı olduğu yargısı, ikinci bin yılın ilk yılında gerçekleşen trajik hadiselerle haklı gösterilmeye çalışılmıştır. 11 Eylül 2001 tarihinde Amerika Birleşik Devletleri'nde meydana gelen saldırılarda kapitalizmin simgesi hâline gelen Dünya Ticaret Merkezinin İkiz Kuleleri yerle bir olmuş, A.B.D. Savunma Bakanlığı ve Genelkurmay Başkanlığı Pentagon'a isabet ettiği rivayet edilen bir uçak sonucunda bir kısmı tahrip olmuştur. Beklendiği gibi bu olay büyük bir infiale yol açmış, sorumlular tespit edilmeye çalışılmış ve çok geçmeden bu eylemleri planlayanların ve gerçekleştirenlerin Müslümanlar olduğu kamuoyuna duyurulmuştur. Asırlardan beri İslam'ı bir “kılıç dini" olarak görenler açısından bu trajik olay malumun ilamı kabilinden bir tepkiyle karşılanırken İslam'1 şiddetle eşitleyen denklem daha da genişletilerek İslam artık terörizmle özdeş hâle getirilmiştir. Danimarka'da Jyllands Posten adlı gazetede 30 Eylül 2005 tarihinde yayımlanan karikatürler İslam karşıtı Batılıların zihnindeki olumsuz imajı son derece somut bir şekilde yansıtmaktadır. Karikatürlerden birinde kara ve kalın kaşlı, kızgın bakışlı, kaba sakallı, başında siyah bir sarık taşıyan bir kafa resmedilmiştir. Siyah renkli sarı̆̆ın ortasında Arapça harflerle tuğra şeklinde bir kelime-i tevhit yer almaktadır. Sarığın orta kısmı büyü bir daire şeklindedir. Dairenin yukarısına bakıldığında bunun aslında fitili alevlendirilmiş bir bomba olduğu görülmektedir. ${ }^{1}$ Diğer karikatürde ise sadece gözleri görünen kara çarşaf giyinmiş iki kadın ortasında kaşları ve sakalı oldukça dağınık, başında beyaz bir sarık ve elinde bir kılıç tutan bir erkek resmedilmektedir. Resmin arka plan rengi yeşildir. ${ }^{2} 2006$ 'da Fransız "mizah" dergisi Charlie Hebdo, Jyllands Posten' in yayımladı̆̆ on iki karikatürü tekrar yayımlamıştır. ${ }^{3}$ Aradan on dört yıl geçtikten

1 Resme ulaşllabilecek adreslerden biri: https://en.wikipedia.org/wiki/File:Jyllands-Posten-pg3-article-in-Sept-30-2005-edition-of-KulturWeekend-entitledMuhammeds-ansigt.png. Erişim: 30 Ekim 2020.

2 https://icyseas.files.wordpress.com/2015/01/mohammed04-0.jpg. Erişim: 30 Ekim 2020.

3 Derginin kapak kısmında siyah sarıklı, siyah elbiseli diz çökmüş vaziyette iki eliyle gözyaşlarını silen siyah sakallı bir karakter yer almakta ve sol tarafta şu ifadeye yer verilmektedir: "Muhammed köktendinciler tarafından ezildi". Ağla- 
sonra 2 Eylül 2020 tarihli sayısının kapak kısmında hem 2006 yılındaki çıkan sayının kapak resmi hem de Danimarkalı gazetenin yayımladığı karikatürler bir kez daha yayımlanmıştır. Dünyanın birçok yerinde Müslümanların tepkisiyle karşılaşmasına ve hatta çok sayıda insanın bu gösterilerde hayatını kaybetmesine rağmen aynı imgelerin "ifade özgürlüğü" adına servis edilmesi İslamofobların önyargılarından vazgeçmeyeceklerinin açık bir göstergesidir.

İslam'ı sadece şiddetle değil aynı zamanda terörle özdeşleştiren bu söylem, sadece siyaset arenasında ya da basın yayın organlarınca gerçekleştirilmemiştir. Bu yaklaşıma bilim camiasından da pek çok katılanlar olmuştur. Belirli çıkarları hedefleyen siyasi hamlelerin gerçekleşmesine matuf ya da bir ideolojiye hizmet edinmeyi kendisine gaye edinmiş oluşumları hedeflerine ulaştırma doğrultusunda üretilen söylemlerin simülakra niteliğinde oluşu izahtan varestedir. Asıl mesele, bir söylemin bilimsel nitelikte olduğu iddiasında bulunulduğu zaman ortaya çıkmaktadır. Çünkü bilimin temel gayesi, birilerinin doğrusuna değil, mutlak doğruya ulaşmaktır. Modern Din Bilimlerinin kurucu babası sayılan Friedrich Max Müller (18231900) bu disiplinin teorik altyapısın belirlerken bu alanda faaliyet gösteren bilim adamının değer yargılarından uzak ve tarafsız, yani objektif olması gerektiğinin altını çizerek şu ikazda bulunur: "Bilimin partizanlara ihtiyacı yoktur".4

İslam'ın bir şiddet dini olduğu yönündeki söylemin Dinler Tarihi alanındaki örneklerinden biri Uluslararası Dinler Tarihi Derneği tarihi tarafından mutat olarak beş yılda bir düzenlenen uluslararası kongrelerinden on dokuzuncusunda görülmüştür. 25-30 Mart 2005 tarihleri arasında Japonya'nın başkenti Tokyo'da düzenlenen

maklı bu karakterin ağzından şu ifadeler dökülmektedir: "Geri zekâlılar tarafından sevilmek zordur". Resme şu adresten ulaşılabilmektedir: https://imgix.bustle.com/lovelace/uplo-

ads/339/371f42c079710132439b0ebc4eccb42f.png?w=760\&h=976.130536130536\&a uto=format $\% 2$ compress\&cs $=$ srgb\& $=70 \&$ fit $=$ crop\&crop=faces. Erişim: 30 Ekim 2020.

4 F. Max Müller, Introduction to the Science of Religion (London: 1899), 26, 28. Müller, Dinler Tarihinin görevinin bir dini itibarsızlaştırmak ya da yüceltmek olmadığını ve böyle yapanların da birbirlerinden farkının bulunmadığını şöyle dile getirmektedir: “İnsanlığın diğer dinlerini yücelterek Hıristiyanlığı gözden düşürmek için karşılaştırmalı bir din incelemesini kullananlar, bana göre Hıristiyanlığ yüceltmek için diğer tüm dinleri gözden düşürmenin gerekli olduğunu düşünenler kadar tehlikelidirler. 
İslam Karşıtı Söylemi Bilimsellik Kisvesine Büründürmek: Hans G. Kippenberğ Örneği bu kongreye 66 ülkeden 1650 bilim adamının katılmış, yedi gün boyunca 1.400'den fazla bildiri sunulmuştur. Bu kongrede dikkat çeken tebliğlerden biri, Bremen Üniversitesi öğretim üyelerinden teolog ve dinler tarihçisi Hans G. Kippenberg'in 27 Mart Pazar günü akşamı verdiği "Preparing for a Ghazwa: The Spiritual Manual of the Attackers of 9/11 [Gazveye hazırlık: 9/11 Saldıranlarının Manevî Rehberi]" konulu konferanstır. ${ }^{5}$ Bu konferansta Kippenberg tarafından dile getirilenler, 11 Eylül 2001 olaylarından sonra Batı dünyasında bir kısım çevreler tarafından oluşturulmaya çalışılan yeni bir İslam imajı ya da daha doğrusu asırlardan beri devam eden İslam'ın bir şiddet dini olduğuna dair söylemin güncel bir versiyonuna tipik bir örnek teşkil etmektedir. Uluslararası Dinler Tarihi Derneği başkanı Peter Antes' in "günümüzün en önemli Alman dinler tarihçilerinden biri" olarak takdim ettiği hemşerisi Kippenberg, 11 Eylül olaylarının İslam ile bağlantılı olduğu için bu bağlantıları bulmak gerektiği düşüncesiyle konferansına başlar. Bu sözde bağlantıları oluşturmak üzere Alman teolog, bu olayları tertipleyen dört saldırgandan üçüne ait farklı yerlerde FBI tarafından bulunarak daha sonra yayımlanan bir "Spiritual Manual [Manevi Rehber]" diye adlandırdığ 1 dört sayfalık bir mektup şeklinde yazılan belgeden hareketle tezini savunmaya çalışır. Kippenberg, bu olayların, örneği İslam tarihinde sıkça görülen gazvelere benzediğini dolayısıyla da bu tür şiddet olayları gerekçelerini İslam tarihinde var olan olgulardan aldığını iddia eder. Kippenberg'e göre “ABD’nin ‘Teröre Karşı Savaşı'dan daha fazlasına ihtiyacımız var: Şiddet eylemlerini mümkün kılan söylemleri ve sosyal oluşumları eleştirel yönden incelemeliyiz" ${ }^{6}$

$\mathrm{Bu}$ çalışmadaki amaç, bir dinler tarihçisi dolayısıyla bir bilim adamı hüviyetiyle İslam hakkında konuşan Kippenberg'in söylemini analiz ederek bilimsellik kamuflajı altında İslam karşıtı imajın nasıl ayakta tutulmaya çalışıldığını anlamaktır. Yaklaşımımız apolojetik ya da polemik olma niyetinde değildir. Bilim etiği övmeyi ya da yermeyi değil, doğruya, gerçeğe, hakikate ulaşmayı gerektirir.

5 Kongrenin ana programına resmî sitesinden ulaşılabilir: http://www.l.utokyo.ac.jp/iahr2005/e1_0.htm. Erişim: 30 Ekim 2020.

6 Congress Secreteriat of the 19th World Congress of IAHR, The Book of Abstracts (Tokyo: 2005), 44-45; IAHR, Programme (Tokyo: 20005), 29. 


\section{"Belge"nin Hikâyesi}

28 Eylül 2001 tarihinde FBI' $n$ düzenlediği basın toplantısında el yazısıyla yazılmış dört sayfalık Arapça bir belge dağıtılmış ve söz konusu bu dört sayfalık belge İnternet sitesinde hiçbir yorum eklenmeden "Hijacking Letter Found at Three Locations [Uçak Kaçırmaya İlişkin Üç Mahalde Bulunan Mektup]" başlığıyla yayımlanmıştır. ${ }^{7}$ Aynı gün Bob Woodward imzasıyla The Washington Post gazetesinde çıkan yazıda beş sayfalık bir belgeden bahsedilmektedir. ${ }^{8}$ Büyük bir ihtimalle Amerikalı yetkililer tarafından servis edilen 11 Eylül saldırılarını düzenleyen saldırganların lideri olduğu ifade edilen şahsın el çantasından çıkan belgenin ilk sayfasından iki kesit yayımlamıştır. ${ }^{9}$ Birinci kesitte, besmeleden sonra şu ifadeler yer almaktadır: "Allah'ın, kedimin ve ailemin adıyla... Allah'ım bütün günahlarımı bağışlaman ve seni mümkün olan her biçimde methetmeme imkân vermen için sana dua ediyorum". ${ }^{10}$ Washington

$7 \quad$ Bu belge FBI'in sitesinden kaldırılmıştır. Ancak söz konusu sayfa görüntüsüne şu adresten ulaşllabilmektedir: https://www.flight93friends.org/images/learning-center/LastNightLetterPressRelease_FBI.jpg. Erişim: 30 Ekim 2020. FBI'in sunduğu bu dört sayfalık belgeye ulaşllabilecek internet adresi: https://www.flight93friends.org/pdf/learning-center/crime-scene-investigation/photos_of_the_last_night_document_exhibited.pdf. Erişim: 30 Ekim 2020.

8 Bob Woodward, In Hijacker's Bags, a Call to Planning, Prayer and Death 28.09.2001. https://www.washingtonpost.com/archive/politics/2001/09/28/in-hijackers-bagsa-call-to-planning-prayer-and-death/fd0bd532-6dec-4b98-8979-7ab0e1894e99/ Erişim: 30.10.2020.

9 Resmî hikâyeye göre sözde elebaşları olduğu saldırıların tasarlandığı gün aktarmalı bir uçuşa binerken bagajlarından biri uçağa alınmamıştı. Mektuplardan biri bu bagajda bulunmuştur. 11 Eylül Komisyonu Raporuna göre "kendisinin uçağa bindiği onaylanmadıkça kontrol edilen bagajların dışarı çıkarılacağı söylendi". Komisyon, The 9/11 Commission Report: Final Report of the National Commission on Terrorist Attacks upon the United States (New York: W. W. Norton, 2004), 1. Bu bagajın neden uçağa alınmadığına dair bu ifadenin doğru olmadığını savunan Rowland Morgan ve Ian Henshall'a göre ise bagaj uçağa hiç alınmamıştı. Bagajın neden uçağa alınmadığı konusu gizemini korumaya devam ederken mantığ kurcalayan daha önemli bir soru ortaya çıkmaktadır: Bir intihar saldırısı düzenlemek üzere yola çıkan ve yolculuklarının kesin ölümle sonuçlanacağını bilen insanlar yanlarında neden bagaj taşısınlar? Ian Henshall ve Morgan Rowland, 9/11 Revealed: The Unanswered Questions (New York: Carroll \& Graf Publishers, 2005), 182.

10 Bruce Lincoln, Holy Terrors: Thinking About Religion After September 11 (Chicago: University of Chicago Press, 2006), 97. Lincoln, sayfa numarası vermeden Holy Terrors: Thinking About Religion After September 11 adlı kitabının sonundaki ilk ek olarak "Final Instructions to the Hijackers of September 11, Found in the Luggage of Mohamed Atta and Two Other Copies" başlı̆̆ıyla belgenin bir çevirisin yayınlamıştır. Eksik olan ilk sayfanın çeviride yer alması dikkat çekicidir. 
İslam Karşıtı Söylemi Bilimsellik Kisvesine Büründürmek: Hans G. Kippenberg Örneği Post'ta çıkan Woodward'ın yazısından bir gün sonra Robert Fisk'in İngiltere merkezli Independent gazetesi için kaleme aldığı makalede belgenin İngilizce çevirisinde bile tuhaf ve mantıksız ifadelerin var olduğuna dikkat çekilmektedir. Fisk'e göre "sorun şu ki, hiçbir Müslüman -tahsil görmemiş olsa bile- ailesini böyle bir duaya dâhil etmezdi. Bilakis ilk sırada Allah'1 zikrettikten hemen sonra Hz. Muhammed'di zikrederdi". ${ }^{11}$

Belgenin servis edilmesinden hemen sonra Arapça asıldan birçok İngilizce çeviri yapılmıştır. ${ }^{12}$ Bunlardan bir tanesi, 17 Ocak 2002 tarihli The New York Review of Books dergisi tarafından yayımlanmıştır. Hassan Mneimneh'in yaptığı tercümenin başında çevirmenin Kanan Makiya ile birlikte yazdıkları uzun bir metin analizi yer almaktadır. İlginç olan husus, yazarların The Washington Post'un yayımladığı kesitlerden bahsederken metnin besmele ile başladığını dile getirdikten sonra besmeleden sonra "Peygamber'in İslam devletini kurarken... Kâfirlere karşı savaşını hatırla" 13 cümlesiyle devam edildiğini ifade etmeleridir. Fisk'in İngilizce tercümede bile aşikâr biçimde göze çarpan anormallikleri bu iki Arap kökenli mütercimin orijinal metinde nasıl görmedikleri şayan-1 hayrettir.

CBS News'un ismini vermediği üç Arap bilim adamına yaptırdığı tercümenin başında bunların belgeye ilişkin görüşlerine yer verilmiştir. Belge hakkında uzman kişiler tarafından yapılan bu tespitlerin öneminden dolayı olduğu gibi aktarmayı faydalı buluyoruz. 1 Ekim 2001 tarihinde yayımlanan bu tercümeyi yapan çevirmenlerin belge ile ilgili gözlemleri birkaç noktada şunlardır:

(1) Bu metnin yazara dikte ettirildiği kanaatindeyiz. Hemen hemen her paragraf bir uzun cümleden oluşmaktadır. Çok az virgül, nokta; çok az açık başlangıç ve açık son var ki bunlar belgeyi oldukça tutarsız kılmaktadır. Aslında, bu belgede yer

11 Robert Fisk, What Muslim would write: 'The time of fun and waste is gone'? 9. 3. 2014. https://www.independent.co.uk/news/world/americas/what-muslimwould-write-the-time-of-fun-and-waste-is-gone-9179397.html. Erişim: 30.10.2020. Bu yazısını Fisk, kitabında yeniden neşretmiştir. Fisk, The Great War for Civilisation: The Conquest of the Middle East (New York: Alfred A. Knopf, 2005), $843 \mathrm{vd}$.

12 Bu çevirilerin küçük biri listesi için bk. Ronaldo Morelos, Trance Forms: A Theory of Performed Sates of Consciousness (Cologne: Lambert Academic Publishing, 200), 302.

13 Kanan Makiya ve Hassan Mneimneh, "Manual of a 'Raid"', Striking Terror: America's New War, Ed. Robert B. Silvers ve Barbara Epstein (New York: The New York Review of Books, 2002), 305. 
alan fikirler, çeşitli türlerden farklı klasik metinlerden alınmış ve net bir amaç veya ajanda olmadan iç içe geçmiş gibi görünmektedir. El yazısı, yazarın kendisine dikte ettirilene yetişmek için çabaladığı izlenimi uyandırmaktadır. (2) El yazısı, bir erkeğin değil bir kadının eline aittir. Örneğin, bir kadının "s"si ile bir erkeğinki arasındaki kaligrafik farklılıklardan dolayı durumun böyle olduğuna inanıyoruz. Bu belgede birkaç farklı kaligrafi stili vardır. Buna en açık örnek, aşağıda çevrilmiş ilk sayfanın diğer üçünden tamamen farklı bir yazı stiline sahip olmasıdır. Ancak bu ilk sayfada bile, kullanılan birçok yazı stili vardır. Sayfanın alt kısmında, son birkaç paragrafta, "Allah" kelimesi en az 4 farklı Arapça yazı stiliyle yazılmıştır. (3) Bu metnin tutarsız doğası nedeniyle kimin konuştuğundan, kimin bu mektubu dikte ettirdiğinden, bu mektubu hangi amaç için dikte ettiklerinden ve bu mektubu kimi muhatap alarak yazdıklarından emin olamayacağımız konusunda hemfikiriz. Bu mektupta imza yoktur. Bu özetteki içerik, hiçbir şekilde bir hava korsanına veya bir teröriste yönelik talimatlar gibi görünmüyor. Herhangi bir biçimde herhangi bir hedefe karşı terör misyonları hakkında da bir şey söylemiyor. Aslında, kanaatimize göre bu, bir intihar notu bile değildir. Yazarın hangi uyruğa ait olduğuna işaret eden herhangi bir kanıt yoktur; ancak kullanılan Arapça tarzından yazarımızın anadilinin Arapça olmadığı anlaşılıyor. Ve eğer onun anadili Arapçaysa söz konusu bu şahıs tahsil görmemiş birisidir. ${ }^{14}$

Belgeyle ilgili bu filolojik problemler yanında onun tek ve resmi bir kaynak tarafından ileri sürülmüş olması mevsukiyeti hakkında en başından kuşkular uyandırdığı gibi geçen zamanla bunlar yok olmak yerine daha da artmıştır. Münferit şahıslar ya da kurumlar tarafından kendi çıkarları doğrultusunda sahte belgelerin düzenlendiğini tarih bize göstermektedir. Bunların en önemlilerinden biri "Konstantin'in Vakfı" adlı belgedir. Hümanizm akımının öncülerinden biri olan İtalyan Lorenzo Valla (1407-1457), 4. Yüzyılda Roma İmparatoru Büyük Konstantin'in Roma ve Roma İmparatorluğu'nun batı kesiminin idaresini Papa'ya devrettiğine dair bu belgenin birkaç yüzyıl sonra papalar tarafından kendi siyasi otoritelerine dayanak oluşturmak için uydurdukları bir belge olduğunu metin analizi ve eleştirel tarih sonucunda ortaya koymuştur. Diğer bir

14 CBS News, Translated Text: Hijackers' How-To. 01.09.2001. https://www.cbsnews.com/news/translated-text-hijackers-how-to/. Erişim: 30.10.2020. 
İslam Karşıtı Söylemi Bilimsellik Kisvesine Büründürmek: Hans G. Kippenberğ Örneği belge sahtekârlığı ise Hıristiyan geleneğine göre çarmıhta öldükten sonra kefene sarılarak bir kaya mezarına konulan İsa'nın bedenine sarılan ve "Torino Kefeni" diye meşhur olan 4,42 x 1,13 metre ebadında bir bez parçasıdır. İsa'nın siluetinin ve özellikle yüz hatlarının izlerinin çok net bir şekilde görüldüğü diğer taraftan el ve ayak bölgelerinde kan izlerinin fark edildiği bu kefen, Hıristiyanlar tarafından İsa'nın çarmıha gerildiğine dair paha biçilmez değerde bir tarihi delil kabul edilmiştir. Zira bu bez, Hıristiyanların kutsal kitapları İncillerde anlatılan hikâyeleri ve dolayısıyla da kendi inançlarını doğruluyordu. Ancak 1988 yılında karbon 14 testiyle yapılan tarihlendirme bu bezin, 13.-14. yüzyıllara ait olduğunu göstermiştir. ${ }^{15}$

\section{Kippenberg'in Analizleri}

Almanya Dinler Tarihi Derneği'nin (Deutsche Vereinigung für Religionsgeschichte) 2003 yılında Erfurt Üniversitesi Max Weber Kolleg'de düzenlediği “Din ve Çatışma” konulu toplantıda Amerikalı yetkililerin ifşa ettikleri mektup tartışılmıştır. Bu yuvarlak masa toplantısında sunulan bildiriler 2004 yılında kitap hâline getirilmiştir: Terror im Dienste Gottes. Die 'Geistliche Anleitung' der Attentäter des 11. September 2001 [Tanrı'nın Hizmetinde Terör. 11 Eylül 2001'deki Suikastçilerin 'Manevi Rehberi'] (Frankfurt/New York). Bazı değişikliklerle İngilizce tercümesi yapılan kitap, 2006 yılında şu başlıkla yayımlanmiştır: The 9/11 Handbook: Annotated Translation and Interpretation of the Attacker's Spiritual Manual [9/11 El Kitabı: Saldırganların Manevi Rehberinin İzahlı Tercümesi ve Şerhi] (London/Oakville).

Diğer taraftan bu yazının başında sözü edilen Tokyo kongresinde Kippenberg'in sunduğu konferansın, Uluslararası Dinler Tarihi Derneği'nin çıkardığı ve Kippenberg'in de 1989-2000 arasında editörlüğünü yaptığı Numen dergisinin "Din ve Şiddet" özle sayısinda çıkan "'Consider That It Is a Raid on the Path of God': The Spiritual Manual of the Attackers of 9/11 başlıklı ["Tanrı Yolunda

15 Bilimsel gerçeklere rağmen Kilise, bu bezin İsa'nın çarmıhta gerildikten sonra bedenine sarılmış olan kefen olduğu yönündeki inancını korumaya devam etmektedir. Mitin tarihin önüne geçişini yansıtan bu tavır, Papa John Paul II'nin Torino'da 1998 yılında yaptığı konuşmada net bir şekilde görülmektedir. Papa'ya göre "Mümin için her şeyden önce önemli olan, bu kefenin, İncil'in aynası olmasıdır". John Paul II, "Address of His Holiness John Paul II", Libreria Editrice Vaticana. 24.05.1998. http://shroudnm.com/docs/JPII05-24-1998.pdf. Erişim: 10 30, 2020. 
Gazve Olduğunu Düşün": 9/11 Saldırganlarının Manevi Rehberi] makaleye dayandığı anlaşılmaktadır.

Kippenberg'in 11 Eylül hadiselerini dinî bir meseleye indirgeme çabasının devam ettiğini Oxford Research Encyclopedias veritabının din bölümü için Nisan 2016 tarihinde hazırladığı "Religious Foundations of the Last Instructions of 9/11 [9/11'deki Son Talimatın dini Temelleri]" başlıklı yazıdan da anlamak mümkündür.

11 Eylül 2001'de ABD'ye terör saldırıları yapan dört kişilik ekibin üçünde Arapça yazılmış dört sayfadan oluşan bir talimatname bulunduğunu ifade eden Kippenberg'e göre bu belge saldırı eylemini, İslam tarihinin ilk dönemlerinde görülen gazveler şeklinde tasarlanmıştır. ${ }^{16}$ Belge, "ekip mensuplarına gazveyi düzgün bir şekilde nasıl gerçekleştireceklerini öğretti. Bunlar, niyetlerini [Kur'an ve zikir] okumaları, ritüeller ve bedensel temizlikle arındırarak saldırılarını bir ibadet eylemine dönüştürdüler. [Belgede] "İkinci aşama" olarak adlandırılan bölüm, havaalanında ilahi korumanın sağlanması konusunu öngörüyor. Son olarak "üçüncü aşama” ekipleri, Peygamber'in uygulamasına göre uçakta hareket etmeye ve şehit olmaya teşvik ediyor". ${ }^{17}$

$\mathrm{Bu}$ rehberi ve onun şiddete meydan verişini Kippenberg altı boyutta analiz etmektedir. Bu süreçte: “(1) Belgenin orijinalliğine yönelik ve aleyhindeki argümanlar ele alınmıştır. (2) Saldırı, 1998'de

16 Kitab-1 Mukaddes'in Eski Ahit bölümünde Kenan diyarında yaşayan halkları topyekûn katletmeyi emreden (Tesniye, 7:2; 20:16-17; Yeşu, 11:8-12) pasajları ya da Matta İncili'ndeki İsa'nın "Yeryüzüne barış getirmeye geldiğimi sanmayın! Ben barış değil, kılıç getirmeye geldim" (Matta 10/34) sözünü hatırlatan Ingmar Karlsson hiç kimsenin bu pasajları öne sürerek Yahudi ve Hıristiyan etiğini yansıttığını göstermeyi düşünmediğine dikkat çektikten sonra yüzyıllar boyunca Avrupalıların cihat kavramı üzerinden bir retorik geliştirerek fanatik, öğretisini kılıçla yayan ve hâlâ bugün de başkalarına şiddet yoluyla kendine kabul ettiren bir İslam imajını benimsetmeye çalıştıklarına vurgu yapmaktadır (Ingmar Karlsson, Din, Terör ve Hoşgörü (İstanbul: Homer Kitabevi, 2005), 164. İslam'ın ticaret yollarıyla ve silah kullanmaksızın karadan batıda Nijerya'dan doğuda Çin'e kadar yayıldığını ve denizden de Madagaskar, Zanzibar ve Hindistan gibi uzak ülkelere ve buradan da Hintli tüccarlar vasıtasıyla Malezya adalarına kadar ulaşttğ̆ gerçeğini adeta göz ardı eden Kippenberg, İslam'ın Müslüman olmayanlara yönelik öğretisini, "kılıç ayeti" diye adlandırdığı Tevbe Suresi'nin beşinci ayetine indirgemektedir.

17 Hans Kippenberg, "Religious Foundations of the Last Instructions of 9/11" Oxford Research Encyclopedia of Religion. 05.05.2016. https://oxfordre.com/religion/view/10.1093/acrefore/9780199340378.001.0001/acr efore-9780199340378-e-83. Erişim: 30.10.2020. 
İslam Karşıtı Söylemi Bilimsellik Kisvesine Büründürmek: Hans G. Kippenberğ Örneği Usame bin Ladin ve diğer cihatçı grupların liderleri tarafından imzalanan "Yahudilere ve Haçlılara Karşı Dünya İslami Cihat Cephesi" tarafından yapılan savaş ilanının ardından gerçekleşti. (3) Mesaj İnternette yayıldı ve İslam'ın durumunu tehdit olarak gören çeşitli gruplar tarafından kabul edildi -bunlar arasında Hamburg'da bir grup genç Müslüman vard1-. El-Kaide denilen bir ağ ortaya çıtı. (4) Günümüz dünyasında cehalet ve kibrin gücü hâkimdir. Rehber, Peygamber'in Medine'deki baskınları (gazve) doğrultusunda bir saldırı öngörmüştür. (5) Rehber, militan Müslümanları örgütlemek için özel bir ortak şekil varsayıyor. (6) Müslümanların militanlığını kabul ediyor ve diasporadaki bir savaşçının etiğini var sayıyor. $A B D$ ve müttefikleri tarafından askeri olarak ortadan kaldırılması hedeflenen bir kötülük ve ahlaksızlık tezahürü olarak Amerika'ya ait terörizm kavramının, çatışmanın seküler karakterini göz ardı ettiği ve şiddet döngüsünü hızlandırdığı yönünde bir iddia ileri sürülmektedir" ${ }^{18}$

Bütün varsayımlarını bu dört sayfalık el yazısıyla düz çizgili mektup kâğıdına yazılmış ve 11 Eylül olaylarını düzenleyen üç şahısta bulunduğu iddia edilen bir metne dayandıran Kippenberg'in yazılarında ilk yaptığı şey, bu belgenin mevsukiyetini ortaya koymak olmuştur. Dinler Tarihinde sahtecilik olayına sıkça rastland1ğını hatırlatan Kippenberg'e göre belge için böyle bir şey söz konusu değildir. Çünkü kuşkuyu ispat edecek hiçbir ciddi girişimde bulunulmamıştır. Hayati meseleler aydınlığa kavuşturulmamıştır. Bu noktada Kippenberg'in tuhaf akıl yürütmesini takip etmek oldukça güçleşmektedir: "Sahtecilikten kim sorumlu olabilir? Bunun amacı ne olabilir? Kim ve hangi amaçlı belgeyi kullanmıştır? Bu sorulara hiçbir cevap verilmediği için sahtecilik kavramının hiçbir bilimsel değeri yoktur". ${ }^{19}$ Tüm kuşku ve belirsizliklere rağmen söz konusu "belgeyi" oldukça ciddiye alan Kippenberg'in temel gerekçesi şudur: Sahtekârlık ihtimaliyle ilgilenmek yerine saldırganların cinayetlerine atfettikleri anlamı yeniden oluşturma konusunda eşsiz bir fırsatı kaçırmamak için çok iyi nedenler vardır. ${ }^{20}$

\footnotetext{
18 Kippenberg, "Religious Foundations of the Last Instructions of 9/11".

19 Kippenberg, "'Consider That It Is a Raid on the Path of God': The Spiritual Manual of the Attackers of 9/11" Numen 52/1 (2005): 34.

20 Kippenberg, "'Consider That It Is a Raid on the Path of God', 35. Aradan yıllar geçmesine rağmen 11 Eylül olaylarıyla ilgili birçok soru hâlâ cevap beklemektedir. 2004 yılında yayımlanan 11 Eylül Komisyon Raporu'nda 11 Eylül'e ilişkin
} 
Kippenberg, kurmacasına devam ederek bütün saldırganların "muhtemelen" belgeyi bildikleri ve eylemlerine onu okuyarak ya da dinleyerek başladıklarını var sayar. ${ }^{21}$ Belgeyi Tilman Seidensticker, Albert Fuess ve Moez Khalfaoui ile birlikte tercüme eden Kippenberg versiyonu asıl dokümanın sadece dört sayfasından ibarettir. İlk sayfa tercüme edilmemiştir.22 İkinci sayfadan başlayan çeviride bu sayfa ilk sayfa olarak gösterilmiştir. Bu çevirinin ilk başlığ "Son Gece (El-leyletu'l-Ahira)"dir. Bu bölümde, eylemden bir önceki

resmî açıklamaları inceleme konusu yaptıkları çalışmalarında Ian Henshall ve Rowland Morgan son derece ciddi bir soruyu gündeme getirmektedirler: $11 \mathrm{Ey}-$ lül olaylarına ilişkin hikâye gerçekten doğru mu? Henshall ve Morgan, 9/11 Revealed: The Unanswered Questions, xii. Resmi hikâyeyi sorgulayanlardan bir diğeri Elias Davidsson'dur. 2013 yılında yayımlanan Hijacking America's Mind on 9/11: Counterfeit Evidence başlıklı çalışmasında Davidsson, olaylarla ilgili bütün aşamaları en başından ele alıp en ufak ayrıntısına kadar gözden geçirerek ve mevcut bütün delilleri hesaba katarak olaylarla ilgili resmi anlatıyı adeta bir yapı çözümüne tabi tutmaktadır. Kitaba önsöz yazan Barrie Zwicker'in ifadesiyle "Elias Davidsson tarafından bu kitapta özenle toplanan deliller birer birer 11 Eylül olaylarını menfur bir sahte terör bayrağı olduğunu ortaya koyuyor... Davidsson, ABD Hükümeti'nin, zanlıların kaçırdıkları iddia edilen uçağa bile bindiklerine dair kanıt sunmadaki başarısızlığını göstererek 19 Müslüman hava korsanı mitini paramparça ediyor: Bunların isimleri tasdikli yolcu listelerinde yer almamaktadır; kimse onların uçağa bindiğini kimse görmemiştir; havaalanlarında olduklarını kanıtlamak için hiçbir doğrulanmış güvenlik kamerası kaydı sunulmamıştır, onların cesetleri resmi olarak tespit edilmemiştir". Barrie Zwicker, "Preface", Hijacking America's Mind on 9/11: Counterfeit Evidence içinde, yazan Elias Davidsson, 1-4 (New York: Algora Publishing, 2013), 1-2. Zwicker ise kendi kanaatini şu şekilde dile getirmektedir: "Bu kitap, 11 Eylül'e dair resmi hikâyeye inanmayışımızın haklı olduğunu, canice bir komplo olduğuna dair teorimizin gerçeklere dayandığını ve 11 Eylül hikâyesinin bir teori bile değil, sadece büyük bir yalan olduğunu doğruluyor" (Zwicker, "Preface”, 4). Hukuk dergilerde İngilizce yayımlanan yüzden fazla makaleyi inceleyen Davidsson, 11 Eylül hakkında yazılan bu bilimsel makalelerin yazarlarının hiçbirinin olaylarla ilgili resim anlatıyı sorgulamadan kabul ettiğini tespit ettikten sonra dünya çapında neredeyse tüm akademik camianın bu miti benimsediğini ve akademik literatürde onun bilimsel bir kisveye büründürüldüğünü söylemenin abartılı olmayacağına dikkat çekmektedir (Davidsson, Hijacking America's Mind on 9/11: Counterfeit Evidence, 309). Davidsson'un vardığı nihai sonuç şudur: "11 Eylül katliamı, yeni bir dönemsel düşmanın yaratılmasını gerekli kılan bir emperyal stratejinin doğal sonucuydu. Bunun için binlerce "öz vatandaşını" feda etmesi gerekti." (Davidsson, Hijacking America's Mind on 9/11: Counterfeit Evidence, 315). Kippenberg, "'Consider That It Is a Raid on the Path of God'", 37.

22 Bk. Kippenberg ve Tilman Seidensticker, The 9/11 Handbook: Annotated Translation and Interpretation of the Attacker's Spiritual Manual, (London-Oakville: Equinox, 2006), 11. 
İslam Karşıtı Söylemi Bilimsellik Kisvesine Büründürmek: Hans G. Kippenberg Örneği gece uyulması gereken talimatların yer aldığı şeklinde yorumlanmiştır. Burada maddi ve manevi temizlenme tavsiyeleri yer almaktadır: bedendeki kötü kılların alınması, duş almak, güzel koku sürünmek, Tevbe ve Enfal surelerini okumak, Allah'ın şehitlere vaat ettiği şeyleri tefekkür etmek, Allah'ı sıkça zikretmek, abdest almadan evden ayrılmamak... Belgenin kalan kısmında diğer iki aşama havaalanına gidiş süreci ve uçakta bulunuş esnasında ne şekilde davranılması gerektiği şeklinde yorumlanmıştır. ${ }^{23}$

Amerikan Kongresi ve Başkanı tarafından Kasım 2002 tarihinde 11 Eylül saldırılarını incelemek üzere kurulan komisyon uzun bir çalışmadan sonra olayları en ince ayrıntısına kadar tespit etmeye çalışmıştır. Bu yoğun çalışma sonunda 2004 yılında ortaya çıkan komisyon raporunda Kippenberg'in dört elle sarıldığı belgeden hiç söz edilmemiştir. Kippenberg bu durum karşısında oldukça şaşkındır. Zira "'Manevi Rehber' bütün savaşçılardan saldırılardan önceki gece boyunca ibadetler yapmasını, ayetler okumasını ve dualar edilmesini ister". ${ }^{24}$ Dört sayfalık bir "belgeden" hareketle 11 Eylül 2001 saldırılarını manevi bir renge büründürmeye çalışan Kippenberg'in zorlama yorumlarını komisyon raporu da olumsuzlamaktadır. Saldırganları birer kökten dinci, dini ritüelleri gerçekleştirerek, ayetler okuyup zikir çekerek kendinden geçen bir meczup şeklinde takdim eden Kippenberg ve benzerlerinin savunduğu gibi saldırıları düzenledikleri iddia edilen şahıslar "son gece"lerinde İslami vecd tekniklerini kullanarak kendilerinden geçmek ve manevi bir dönüşüm gerçekleştirmek yerine alelade beşerî işlerle meşgul olmuşlardır. ATM'den para çekmiş pizza yemiş ve marketten alışveriş yapmışlardir. ${ }^{25}$

\section{Sonuç}

Amerikalı tarihçi John Lewis Gaddis, 1989'da yaptığı bir söyleşide Mihail Gorbaçov'un ABD ile dostane ilişkiler kurarak Soğuk Savaş dönemini sonlandırması hâlinde ortaya çıkacak yeni durumla ilgili

23 Örneğin bk. Don Handelman, "Self-Exploders, Self-Sacrifice, and the Rhizomic Organization of Terrorism", Religion, Politics, and Globalization: Anthropological Approaches içinde, Ed. Don Handelman ve Galina Lindquist (New York - Oxford: Berghan Books, 2011): 249-251.

24 Kippenberg, "Background to the Spiritual Manual: Its Discovery, Interrogation, And Disregard", The 9/11 Handbook: Annotated Translation and Interpretation of the Attacker's Spiritual Manual, Ed. H. G. Kippenberg ve T. Seidensticker (LondonOakville: Equinox, 2006), 7.

25 Komisyon, The 9/11 Commission Report, 253. 
endişelerini dile getirmektedir: "Gorbaçov'un bizi bir düşmandan mahrum birakma stratejisi devam ederse, o zaman o unsur mevcut olmayacak ve bir şeyi formüle etmek daha zor olabilir" (Gaddis 1989). Gaddis'e göre Sovyet bloğunun çöküşünden sonra ABD'nin mevcut küresel firsatlardan yararlanmasına olanak taniyan proaktif bir dış politikayı halka benimsetmek için bir dış tehdide ihtiyaç vardi.

1991 yılında Sovyetler Birliği'nin dağılışından birkaç yıl sonra Fransız Le Monde Diplomatique gazetesinin Aralık 1994 tarihinde çıkan sayısında kaleme aldığı yazıda Norwegian Peacebuilding Ressource Center [Norveç Barış Tesis Kaynağı Merkezi] müdürü Mariano Aguirre, "Batı'nın nazarında artık mağlup olan Komünizmin yerini hangi rakip alacaktır?" diye sormakta ve akabinde de şu cevabı vermektedir: Her şey, jeopolitikacıların ve stratejistlerin bu yüzyılın sonundaki "külli düşman" olarak İslamizmi tayin etme noktasında ittifak ettiklerini göstermektedir. Onunla daha iyi mücadele edebilmek için muhafazakâr entelektüeller "medeniyetler çatışması" tezini geliştirirken askerler, bu egzotik hasmı "yıkmak ve yok etmek" için yeni bir savaş doktrini oluşturmaktadırlar [...] Bu yüzyılın sonunda tehlikeler, tehditler ve felaketler, "İslami sahadan" gelecekmiş". ${ }^{26}$

Bu yeni "düşman" karşısında sadece politikacılar, askerler ya da stratejistler harekete geçmemiş sosyal bilimler alanındaki bazı bilim adamları da kendi paylarına düşen katkıyı sağlamaya çalışmışlardır. Harvard Üniversitesi profesörlerinden Samuel Huntington'un "Medeniyetler Çatışma"sı tezi çok sayıdaki örnekten sadece bir tanesidir. Her ne kadar tezi basit ve argümanları orijinallikten uzak olsa da Huntington, kültür savaşı senaryosuyla var olan korkulara hitap etmede başarılı olmuştur.

Hans G. Kippenberg'in 11 Eylül 2001 hadiselerini “Manevi Rehber" diye adlandırdığı ne idüğü belirsiz ve sayfasının biri hiçbir zaman sızdırılmayan beş sayfalık elle yazılmış bir metin çerçevesinde izah etmeye çalışması en basit ifadeyle aşırı bir indirgemeciliktir. Bu olayları tamamıla İslami bir renge büründürmeye çalışan bir gayret bilimsel bir anlayışla yapılmış olamaz. İslam terminolojileri kul-

26 Mariano Aguirre, L'Occident en quête d'un "ennemi total": Guerres de civilisations? http://www.mondediplomatique.fr/1994/12/AGUIRRE/945 Erişim: 13.09.2019. 
İslam Karşıtı Söylemi Bilimsellik Kisvesine Büründürmek: Hans G. Kippenberğ Örneği lanarak konunun uzmanı olduğu izlenimi vererek iddialarını geçerli kılmaya çalışsa da akıl yürütmedeki tutarsızlıklar ve çelişkiler Kippenberg'in bilim adamı hüviyetine ve itibarına halel getirir niteliktedir.

Kippenberg'in tavrı bilimsellikten uzak olduğu gibi aynı zamanda Batılı zihniyetin İslam'a karşı önyargılarını da yansıtmaktadır. Tümdengelimci yaklaşımla bir vakadan, bir belgeden, tarihin tek bir kesitinden hareketle yüz milyonlarca insanı şiddet taraftarı olarak göstermek diğer insanlar nazarında onları bir "düşman" gibi göstermek bilime ve bilim adamlığına hiçbir surette yakışmamaktadir.

Şunu da unutmamak gerekir ki yüzyıllar boyunca Papa'ya bağlı olmayan Hıristiyanları, Zerdüştileri, Yahudileri kendi topraklarında koruyan ve kollayanlar onlara sığınak olanlar Müslümanlar değil miydi? 1492 yılında son Müslüman kalesi Gırnata, Ferdinand ve İsabella'nın ordularının eline geçince o topraklarda yüzyıllardır yaşayan Yahudilerin ve Müslümanların başına neler geldi...

Anlaşılan o ki bir dinler tarihçisi olan Kippenberg'in tarihi, bir kez daha okuması gerekir. Yalnız, bu kez, gözleri önündeki önyargı perdelerini yırtarak. Bilimin partizanlara ihtiyacı olmadı̆̆ gibi tetikçilere de ihtiyacı yoktur.

\section{Kaynakça}

Aguirre, Mariano. L'Occident en quête d'un «ennemi total »: Guerres de civilisations?

http://www.mondediplomatique.fr/1994/12/AGUIRRE/945.

Erişim: 13. 09. 2019.

CBS News. Translated Text: Hijackers' How-To. 01.09.2001. https://www.cbsnews.com/news/translated-text-hijackers-howto/. Erişim: 30.10. 2020.

Davidsson, Elias. Hijacking America's Mind on 9/11: Counterfeit Evidence. New York: Algora Publishing, 2013.

Fisk, Robert. The Great War for Civilisation: The Conquest of the Middle East. New York: Alfred A. Knopf, 2005.

. What Muslim would write: 'The time of fun and waste is gone'? 09.03.2014. https://www.independent.co.uk/news/world/americas/what-muslim-would-write-the-time-of-fun-and-waste-is-gone9179397.html. Erişim: 30.102020. 
Gaddis, John Lewis. Living without External Threat. $8 \begin{array}{lll}8 & 5 & 1989 .\end{array}$ http://globetrotter.berkeley.edu/conversations/Gaddis/gaddiscon3.html. Erişim: 30.10.2020.

Handelman, Don. "Self-Exploders, Self-Sacrifice, and the Rhizomic Organization of Terrorism" Religion, Politics, and Globalization: Anthropological Approaches, 231-262. ed. Don Handelman ve Galina Lindquist, New York - Oxford: Berghan Books, 2011.

Henshall, Ian, ve Rowland Morgan. 9/11 Revealed: The Unanswered Questions. New York: Carroll \& Graf Publishers, 2005.

IAHR, Congress Secreteriat of the 19th World Congress of. Programme. Tokyo, 2005. . The Book of Abstracts. Tokyo, 2005.

John Paul II. «Address of His Holiness John Paul II.» Libreria Editrice Vaticana. 24.05.1998. http://shroudnm.com/docs/JPII05-241998.pdf. Erişim: 30.10.2020.

Karlsson, Ingmar. Din, Terör ve Hoşgörü. İstanbul: Homer Kitabevi, 2005.

Kippenberg, Hans G. "Background to the Spiritual Manual: Its Discovery, Interrogation, And Disregard" The 9/11 Handbook: Annotated Translation and Interpretation of the Attacker's Spiritual Manual, 1-9. Ed. Hans G. Kippenberg ve Tilman Seidensticker. LondonOakville: Equinox, 2006.

Kippenberg, Hans G. "'Consider That It Is a Raid on the Path of God': The Spiritual Manual of the Attackers of 9/11". Numen 52/1 (2005): 2958.

Kippenberg, Hans G. ve Tilman, Seidensticker. The 9/11 Handbook: Annotated Translation and Interpretation of the Attacker's Spiritual Manual. London-Oakville: Equinox, 2006.

Kippenberg, Hans. "Religious Foundations of the Last Instructions of 9/11". Oxford Research Encyclopedia of Religion. 05.05.2016. https://oxfordre.com/religion/view/10.1093/acrefore/97801993403 78.001.0001/acrefore-9780199340378-e-83. Erişim: 30.10.2020.

Komisyon. The 9/11 Commission Report: Final Report of the National Commission on Terrorist Attacks upon the United States. New York: W. W. Norton, 2004.

Lincoln, Bruce. Holy Terrors: Thinking About Religion After September 11. 2. Chicago: University of Chicago Press, 2006. 
İslam Karşıtı Söylemi Bilimsellik Kisvesine Büründürmek: Hans G. Kippenberg Örneği Makiya, Kanan, ve Hassan Mneimneh. "Manual of a 'Raid'" Striking Terror: America's New War, 301-318. Ed. Robert B. Silvers ve Barbara Epstein. New York: The New York Review of Books, 2002.

Morelos, Ronaldo. Trance Forms: A Theory of Performed Sates of Consciousness. Cologne: Lambert Academic Publishing, 2009.

Müller, F. Max. Introduction to the Science of Religion. London, 1899.

Woodward, Bob. In Hijacker's Bags, a Call to Planning, Prayer and Death. 28. 09.2001. https://www.washingtonpost.com/archive/politics/2001/09/28/inhijackers-bags-a-call-to-planning-prayer-and-death/fd0bd5326dec-4b98-8979-7ab0e1894e99/. Erişim: 30.10.2020.

Zwicker, Barrie. "Preface". Hijacking America's Mind on 9/11: Counterfeit Evidence, 1-4. Ed. Elias Davidsson. New York: Algora Publishing, 2013. 